\title{
SOCIAL LEADERSHIP: CRITERIA, INDICATORS AND LEVELS OF FORMATION IN FUTURE SOCIAL WORKERS
}

\author{
Darya Bybyk \\ ORCID iD 0000-0001-9947-8503 \\ Senior Lecturer, $\mathrm{PhD}$ student of the Theory and \\ Technology of Social Work Department, \\ National Pedagogical Drahomanov University \\ 9 Pyrohova Str. 9, 01030 Kyiv, Ukraine \\ dasha.bybyk@gmail.com
}

https://doi.org/10.28925/2518-7635.2020.5.7

\section{ABSTRACT}

Nowadays it is extremely important for society to be aware of the professional and experienced professional training of the future social workers. The article is devoted to the main issue of formation the social leadership in the conditions of professional training the future social workers. Contemporary conditions indicate the need to highlight certain scientific approaches to leadership in social work. It is determined that the theoretical study of the phenomenon of "social leadership" as a social phenomenon at the present stage of development of society determines the search for criteria for its formation in future professionals in the social sphere. On the basis of substantiated criteria (motivational-value, cognitive, activity-behavioral) there are established the corresponding indicators that reflect the characteristic of the manifestation the levels of formation the social leadership at future workers in social work (reactive, active, proactive). The purpose of the research is to determine the criteria, indicators and levels that can further influence the dynamics of social leadership in students - future social workers to improve the current state of society, in particular in the field of social work.

The realization of this goal involved the use of the following methods: scientific knowledge, analysis of scientific literature, synthesis, comparison, generalization, specification, classification, systematization as well as the descriptive method.

Based on the analysis, it is characterized that the components of social leadership and substantiates the criterion, indicators and levels of its formation in accordance with the understanding of the factors of formation of social leadership of future social workers in terms of training.

Key words: social worker; social work; social leadership; criterion; level of formation; indicator.

(C) Darya Bybyk, 2020 


\section{INTRODUCTION}

Nowadays it is extremely important for society to be aware of the professional and experienced professional training of the future social workers. The search of ways to achieve the goals of understanding the content and results of professional activities with the needs of society led to the interest of higher education in training new generation who should have key competencies and be able to organize quality and professional educational activities. The leadership position of future social workers which is externally manifested in leadership behavior and professional activities is also internally determined by a system of leadership orientations, goals and values. Thus, it reflects the nature of needs, motives and beliefs in the specialist's personality of a social sphere.

The successful formation of social leadership will help the future social worker to organically engage in professional work and begin the practical application of leadership knowledge and skills in the process of professional activity. However, it is important to determine the aspiration to study the problem of forming social leadership in the context of training future professionals for social work. The purpose of research is to determine the indicators, criteria and levels of social leadership in future social workers in training which will provide an opportunity to determine the current state and predict the dynamics of social leadership.

\section{ANALYSIS OF PREVIOUS STUDIES ON THE PROBLEM}

Different aspects of leadership, highlighting the content, structure, types and characteristics have received increased attention from foreign and domestic researchers (Hizzatullin, I., Kalashnikova, S.). Specific types of leadership that are more adapted to the values of social work are proposed (Iachini, Cross \& Freedman, 2015, p. 650). Leadership becomes included in social work education based on the model of social change of leadership through the promotion of basic values of social work. It proves the strong position of creating a value base of the profession social work (Iachini, Cross $\&$ Freedman, 2015, p. 650). The use of ideas of change and innovation applies the ideas of transformational leadership where the charisma of the leader determines the motivation and understanding of people as accessibility and inspiration which contributes to achieving both individual and organizational goals (Colby Peters, 2018, p.32). Communities of social work practitioners have significant potential for leadership development through the focus of social learning concepts and the promotion of leadership through knowledge and experience (Haworth, Miller \& Schaub, 2018). At the same time, client-centered leadership (Sullivan, 2016) as an actual model defined by the client or user of social services focuses 
on the motivation and satisfaction of practitioners with social work which are the means to achieve the desired goal and satisfaction of social services to improve difficult life circumstances.

At the same time, the model of adaptive leadership is also important for the field of social work. As the diversity and speed of social change it requires its application in social learning, innovation and adaptation to practical social work (Heiftez et al, 2009). Since the professional practice focuses on the development of social work innovations - the leadership in social work is based on distributed leadership, supporting practical environments related to professional values and purposeful organizational and individual actions (Gibson, 2017, p.8). A common approach in solving social problems allows us to define the essence of leadership as the vision and ability to influence the views and actions of others as well as to inspire and cultivate change (Holosko, 2009, p. 449). The issues of reviewing the concept of leadership-and-serving (Greenleaf, 2008) in various spheres of society continue to study and improve the mechanisms of formation the leadership qualities and leadership potential of individuals of different ages (Nestulia, 2014, p. 46). As a result, attention to leadership research in the field of social work is constantly increasing which determines the decisive influence of the social sphere both locally and globally. Proportionately, this increases the need for research in the field of social leadership (Hizzatullin, I.) as the maximum organizational and managerial principles serve only as a solid foundation for successful and longterm development of its theoretical basis and practical implementation in the field of social work. Thus, "the leader must set the direction, prove own example and share the danger" (Hryzhenko, 2014, p.49).

However, there has been little attention paid to the study and analysis of the phenomenon of social leadership which affects the effectiveness of training for professional activities in modern higher education. Analysis of recent research has shown that the social leadership has increasingly become the subject of research (Structural Analysis of the Notion of Social Leadership, 2015). Thus, the purpose of our article is to analyze, define and substantiate the main criteria, indicators and levels of formation of social leadership in future social workers. Along with this, the criteria and indicators of the formation the social leadership of future social workers remain unexplored.

\section{METHODOLOGY}

The methodology consists of theoretical methods: methods of scientific knowledge, analysis of scientific literature, synthesis, comparison, generalization, specification, classification, systematization. Methodological principles of the process of social leadership formation focus on the main methodological principle of professional training of future social workers on the conformity in the combination of theoretical knowledge, practical 
skills and the formation of appropriate requirements for the acquisition of competencies and leadership skills to ensure maximum effectiveness of the criteria.

\section{THE STUDY}

The professional training of future social workers has a prominent place in the system of higher education. The search and development of leaders are of a particular importance (Kalashnikov, 2016, p. 5). The basis for the formation of social leadership in the field of 23 Social Work is certainly the creation of institutionalized and pedagogical conditions that promote the development, self-development and realization of students future social workers as experienced professionals. The demonstration of the manifestation the social leadership of future social workers plays an important role.

Therefore, it is necessary to define the objective social phenomenon of social leadership as the presence of a social position of the individual in the community or group of people providing the ability to manage and organize the team according to goals and values as well as situational conditions of the social environment (Hizzatullin , 2015, p.16).

The results of our theoretical study are based on the analysis of scientific sources and are devoted to the study of structural analysis of the notion social leadership. As a dynamic integrative social formation it allowed us to distinguish our own definition of the notion social leadership. Thus, social leadership is a process of social workers to implement socially significant and professionallyoriented initiatives, the success of which should contribute to improving the society life's quality.

We have also identified the following provisions:

Social leadership in future social workers is understood as an integral new formation which occurs in a combination of methods, forms and means of formal and informal components of training the social workers.

The formation of social leadership in social workers is a complex process that starts at the stage of training as well as it has certain conditions and specifics of its development.

It should be theorized the notion of social leadership of future social workers as a proactive inclusion to socially significant social activity in accordance with leadership and value orientations in the social sphere. Social leadership of future social workers is a combination of the following elements (Table 1.1): 


\section{Components of the formation the social leadership in future social workers}

\begin{tabular}{|c|c|}
\hline $\begin{array}{c}\text { Elements } \\
\text { of the formation } \\
\text { the social } \\
\text { leadership }\end{array}$ & Informative provision of the elements \\
\hline Motivational & $\begin{array}{l}\text { It characterizes the following items: } \\
\text { - the aspiration of future social workers for global change related } \\
\text { to the awareness of leadership in society; } \\
\text { - a sense of social responsibility of the future specialist; } \\
\text { - as the specialist with leadership skills there is the aspiration } \\
\text { to manage locally the professional activity; } \\
\text { - the formation of leadership motivation in students to organize } \\
\text { the social activities; } \\
\text { - the formation of interest, aiming at the organization of professional } \\
\text { training and the aspiration of improving it through a set of motives } \\
\text { that encourages social workers to study the courses of leadership } \\
\text { as well as the attitude to these courses as the essential component } \\
\text { in further training and practical activities; } \\
\text { - the motives that encourage the leadership activity. }\end{array}$ \\
\hline Informative & $\begin{array}{l}\text { It determines: } \\
\text { - the features of social and community activities; } \\
\text { - the requirements of educational curricula in Social Work; } \\
\text { - the educational curricula of the elective courses that form a system } \\
\text { of students' knowledge about the social leadership on the basis } \\
\text { of the leadership competence in a social worker that in turn } \\
\text { projects the future professional activity. }\end{array}$ \\
\hline Activity & $\begin{array}{l}\text { It ensures: } \\
\text { - the implementation of professional readiness of future social } \\
\text { workers to make an informed choice of self-realization, self- } \\
\text { development and self-improvement as well as professional } \\
\text { and personal growth in the process of professional training; } \\
\text { - the availability of leadership capacity of the individual that } \\
\text { is necessary for the effective organization of social activity. }\end{array}$ \\
\hline
\end{tabular}

According to the structure of social leadership we have identified motivational-value, cognitive and activity-behavioral criteria (Table 1.2) which allow us in terms of professional education to determine the level of formation the social leadership in future social workers (Table 2).

Table 1.2

\section{Criteria of formation the social leadership in future social workers}

\begin{tabular}{|c|l|}
\hline $\begin{array}{c}\text { Motivational- } \\
\text { value }\end{array}$ & $\begin{array}{l}\text { Indicators: leadership orientations, leadership values of social work; } \\
\text { motivation for professional activity, the need of leadership capacity } \\
\text { implementation; orientation towards the leadership style. }\end{array}$ \\
\hline Cognitive & $\begin{array}{l}\text { Indicators: the availability of cognitive interest in awareness of social } \\
\text { leadership; educational activity, the involvement in various types of offline } \\
\text { and online learning; social activity in non-formal learning. }\end{array}$ \\
\hline $\begin{array}{c}\text { Activity- } \\
\text { behavioral }\end{array}$ & $\begin{array}{l}\text { Indicators: leadership skills, activity in classroom and extracurricular social } \\
\text { and educational activities; ability to cooperation and team interaction. }\end{array}$ \\
\hline
\end{tabular}

According to the common validity of formation the indicators of social leadership in future social workers by various criteria there can be provided a modified description of levels of social leadership in future social workers 
in the context of professional education. Thus, we can determine the following levels: proactive, active and reactive.

Table 2

\section{Levels of formation the social leadership in future social workers}

$$
\begin{aligned}
& \text { proactive (high) } \\
& \text { active (medium) } \\
& \text { reactive (low) }
\end{aligned}
$$

\author{
constant manifestation \\ episodic manifestation \\ minimal manifestation
}

In accordance with the scientific research we can conclude that the proactive level is characterized by a constant manifestation of indicators, while the active is characterized by episodic manifestation, and reactive is characterized by a minimal manifestation of indicators of formation the social leadership in future social workers.

Thus, the proactive level of formation the social leadership in students (future social workers) is characterized by following items: high degree of manifestation the leadership orientation, profound knowledge about social leadership, high perception of the leadership in social work, high level of manifestation the values in society, clear awareness and high activity, independence and initiative, manifestation of the motivation, hypersensitivity to social problems and ways to solve them.

Active level of formation the social leadership in students (future social workers) is characterized by the following components: the sufficient degree of manifestation the leadership orientation, the availability of a basic level of knowledge about social leadership, the sufficient perception of the leadership in social work, the basic level of values in society, the sufficient awareness and activity, independence and initiative, the manifestation of motivation, the availability of the sufficient level of hypersensitivity to social problems and ways to solve them.

Reactive level of formation the social leadership in students (future social workers) reflects the insufficient level of formation the social leadership. This level is also characterized by the low set of criteria: high degree of leadership orientation, the availability of a basic level of knowledge about social leadership, the sufficient perception of leadership in social work, the basic level of manifestation the value orientations in society, sufficient awareness and activity, independence and initiative, the manifestation of motivation, the availability of the sufficient level of hypersensitivity to social problems and ways to solve them.

Thus, the social need focuses on the necessity to train future social workers who are raised on value foundations. The students must be able to act effectively in situations of uncertainty, think creative in solving social problems, produce new ideas and unite people around a socially useful goal.

According to the experts' opinion of each group, the results of assessing the indicators of formation the social leadership in future social workers can complement the importance of the level of formation by the following steps: students (future social workers) engagement in the search for information 
about possible participation in various activities and social leadership programs; active participation in various social projects; effective partnership with governmental, non-governmental and business structures to test their own training programs and projects.

In can be generally stated that leadership should evolve in step of changes as the development of leadership capacity of future social workers will contribute to the formation of effective social leadership in Ukraine and ensure high-quality updating the social sphere and the country as a whole (Bybyk, 2018, p. 124).

\section{CONCLUSIONS AND PROSPECTS}

Social leadership is a formation of the specialists' personality of a new generation. It consists of the motivational, cognitive and activity components; and the levels of its formation contain a reactive, active and proactive set of criteria (motivational-value, cognitive and activity-behavioral).

These criteria are characterized by relevant indicators. The use of means in the process of professional training of future specialists in the social sphere will not only completely identify the degree of their readiness for professional activity but also to correct possible drawbacks in time. Thus, the manifestation of social leadership promotes the development of a professionally competent professional who not only has the knowledge and skills but is sufficiently developed, capable of partnership, ready to take responsibility for themselves and their activities, make decisions and see global perspectives.

Thus, based on our research, we highlight the prospects for further research focusing on the experience of forming social leadership in future professionals in the social sphere.

\section{REFERENCES}

Bybyk, D., \& Savelchuk, I. (2018). Social Leadership as a basis for the development of partnerships in the educational environment at the university: Scientific journal National Pedagogical Dragomanov University Series 11: Social Work. Social Pedagogy: Coll. of sciences, (25), 119-125 (in Ukrainian). URI: http://enpuir.npu.edu.ua/handle/123456789/25347

Hizzatullin, I. (2015). Structural Analysis of the Notion of Social Leadership. Pedagogical Education in Russia, (10), 12-16 (in Russian)

Hryzhenko, L. (2014). Leadership as a Social Phenomenon. Hrani, (5), 48-52 (in Ukrainian)

Gibson, M. (2017). Leadership and Practice Development: A literature review. Unpublished, University of Birmingham

Iachini, A., Cross, T. \& Freedman, D. (2015). Leadership in Social Work Education and the Social Change Model of Leadership. Social Work Education. 34(6), 650-665. DOI: 10.1080/02615479.2015.1025738 
Kalashnikova, S. (2016). Development Leadership Qualities of a Modern University: Basics and Means: textbook. Kyiv : Science-Production Center "Prioritety", 44 (in Ukrainian)

ColbyPeters, S. (2018). Defining social work leadership: a theoretical and conceptual review and analysis. Journal of Social Work Practice. 32(1), 31- 44. DOI: https://doi.org/10.1080/02650533.2017.1300877

Nestulia, S. (2014). Leadership and Serving - the concept that Ukrainian Society Needs. Higher Education in Ukraine (№ 4. Appendix. 1. Issue «University and Leadership»), 46-51 (in Ukrainian)

Haworth, Miller \& Schaub (2018). Leadership in Social Work https://www. birmingham.ac.uk/Documents/college-social-sciences/social-policy/Misc/ leadership-in-social-work.pdf

Heiftez, R. etal (2009). The practice of adaptive leadership: Tools and tactics for changing your organisation and the world. Boston, Harvard Business School Press https://www.hks.harvard.edu/publications/practice-adaptiveleadership-tools-and-tactics-changing-your-organization-and-world

Holosko, M. (2009). Social Work Leadership: Identifying Core Attributes. Journal of Human Behavior in the Social Environment (19), 448-459. DOI: $10.1080 / 10911350902872395$

\section{СОЦІАЛЬНЕ ЛІДЕРСТВО: КРИТЕРІЇ, ПОКАЗНИКИ Й РІВНІ СФОРМОВАНОСТІ У МАЙБУТНІХ СОЦІАЛЬНИХ ПРАЦІВНИКІВ}

Бибик Дар'я, старший викладач, $\mathrm{PhD}$ здобувач кафедри теорії та технології соціальної роботи Національний педагогічний університет імені М.П. Драгоманова, вул. Пирогова 9, 01030 Київ, Україна, dasha.bybyk@gmail.com

Підготовка майбутніх соціальних працівників до професійной діяльності є надзвичайно складним та водночас важливим завданням. Стаття присвячена актуальній проблемі бормування соціального лідерства в умовах професійної підготовки майбутніх соціальних праиівників. Умови сьогодення засвідчують потребу висвітлення окремих наукових підходів до лідерства в сочіальній роботі. Визначено, що теоретичне дослідження феномену "соціального лідерства» як сочіального явища на сучасному етапі розвитку суспільства зумовлює пошук критерії його сбормованості у майбутніх фахівців сочіальної сфери. На основі обьрунтованих критеріїв (мотиваційно-иіннісний, когнітивний, діяльнісно-поведінковий) встановлено відповідні показники, щ,о відображають характеристику прояву рівнів сформованості соиіального лідерства у майбутніх працівників соціальної роботи (реактивний, активний, проактивниц). Визначення критеріїв, показників та рівнів, які зможуть в подальшому вплинути на динаміку формування соціаль- 
ного лідерства у студентів - майбутніх працівників соціальної сфери для покращення сучасного стану суспільства, зокрема в галузі соціальної роботи є метою наукового дослідження.

Реалізація поставленої мети передбачала використання методів: наукового пізнання, аналізу наукової літератури, синтезу, порівняння, узагальнення, конкретизації, класифікації, систематизації, а також до описового методу.

На основі проведеного аналізу автором схарактеризовано компоненти соціального лідерства та облрунтовано критерії, показники та рівні його сформованості відповідно до розуміння чинників формування соціального лідерства майбутніх соціальних працівників в умовах професійної підготовки.

Ключові слова: соціальний прачівник, соціальна робота, сочіальне лідерство, критерій, рівень сбормованості, показник.

Received: 30.09 .2020

Accepted: 26.11.2020 